\title{
Effects on Microhymenopteran Progeny of Different Host Exposure Periods (Chrysomya megacephala, Calliphoridae) to the Parasitoid Wasp Nasonia vitripennis (Hymenoptera: Pteromalidae)
}

\author{
Renata da Silva Mello ${ }^{1,2 *}$, Gonzalo Efrain Moya Borja ${ }^{3}$ and Valéria Magalhães Aguiar \\ Coelho ${ }^{4}$ \\ ${ }^{1}$ Laboratório de Transmissores de Leishmaniose; Setor de Entomologia Médica e Forense; Pavilhão Lauro \\ Travassos; Instituto Oswaldo Cruz; Av. Brasil, 4365; Manguinhos, sala A10; 21040-900; Rio de Janeiro - RJ - \\ Brasil. ${ }^{2}$ Programa de Pós-Graduação em Biologia Animal; Instituto de Biologia; Universidade Federal Rural do \\ Rio de Janeiro; Rodovia BR $465 \mathrm{Km}$ 7; 23890-000; Seropédica - RJ - Brasil. ${ }^{3}$ Laboratório de Entomologia; \\ Departamento de Parasitologia Animal; Universidade Federal Rural do Rio de Janeiro; Rodovia BR 465, Km 47; \\ sala 26; 23890-000; Seropédica - RJ - Brasil. ${ }^{4}$ Laboratório de Estudo de Dípteros; Departamento de Microbiologia \\ e Parasitologia; Instituto Biomédico; Universidade Federal do Estado do Rio de Janeiro; Rua Frei Caneca, 94; \\ 20211-040; Rio de Janeiro - RJ - Brasil
}

\begin{abstract}
To test the assumption that exposure of the host to parasitoid for long periods could provoke superparasitism, the aim of this work was to test the consequences on the immature development time, productivity of parasitoids per pupa, sex ratio and rate of parasitism of Nasonia vitripennis bred in Chrysomya megacephala pupae. Each individual pupa was placed in a glass tube with one parasitoid female for 24, 48, 72 and 96 h period of exposure, under controlled laboratory conditions. Twenty replicates of each period were performed. ANOVA with a 5\% significance level was applied. The $72 \mathrm{~h}$ exposure caused the immature development time to increase. The mean parasitoids emergence per pupa did not vary significantly with the time of exposure. There were a significantly higher number of females than males and a trend in sex ratio deviation towards the females in all of the treatments. An increase in the number of unviable pupae rates were observed with increased exposure time.
\end{abstract}

Key words: Biological control, calliphorids, immature development, sex ratio, superparasitism

\section{INTRODUCTION}

The parasitic wasp Nasonia vitripennis (Walker, 1836) (Hymenoptera: Pteromalidae) is an ectoparasitoid of dipteran pupae, such as blowflies, flesh flies and muscid flies. It is considered to be a polifagous species, due to its capacity to parasitize a large number of host species. Whiting (1967) reported the existence of 68 species of cyclorraphan muscoids that were parasitized by $N$. vitripennis and, more recently, a number of new hosts have also been reported (Marchiori, 2004).

This species is widely distributed geographically

\footnotetext{
*Author for correspondence: mellorebio@yahoo.com.br
} 
and is found in all the continents (Rueda and Axtell, 1985). In Brazil, the first report of this species dates back to 1985, and describes the parasitism of Chrysomya sp. (Calliphoridae) pupae (Madeira and Neves, 1985).

In their natural environment, the calliphorid flies use discrete and ephemeral substrates for feeding and laying their eggs or larvae and thus may be vectors of many diseases (Maldonado and Centeno, 2003; Oliveira et al., 2003; Carvalho and Von Zuben, 2006). These flies can also act as egg vectors for Dermatobia hominis (Linnaeus Jr., 1781) (Marinho et al., 2003). In addition, the larvae of these dipterans can cause myiasis in humans and animals (Greenberg, 1973; Guimarães et al., 1983; Furlanetto et al., 1984; Guimarães and Papavero, 1999; Sukontason et al., 2005).

In Brazil, muscoid dipteran control has been performed almost exclusively with the use of insecticides. However, the indiscriminate use of these products may cause severe environmental damage, since they are toxic to living organisms and also induce the development of resistant insects. Therefore, studies relating to the biology of these organisms and their parasitoid-host relationships are important, as they may enable the development of biological control techniques.

Successful parasitism by insect parasitoids is usually divided into hierarchical requirements, consisting of habitat location, host acceptance, and evaluation and physiological regulation of the host (Brodeur and Boivin 2004). The discrimination between a low and high quality host is performed by collection of a small sample of the pupae hemolymph through the parasitoid female ovipositor (Wylie, 1958, 1965; Whiting 1967, King and Ellison, 2006). The females that neglect the host quality and ovipose in an old or cryoconserved hosts (King and Skinner, 1991; Milward-de-Azevedo and Cardoso, 1996) and already parasitized puparium, usually suffer a reduction in the quantity and quality of their progeny. The oviposition in parasitized puparium can due to the occurrence of superparasitism, that refers both to one female ovipositing repeatedly in a single host and to more than one female ovipositing in a single host (Wylie, 1963, 1965; Van Dijken and Waage, 1987).

The aim of this study was to investigate the effects and consequences on the progeny of $N$. vitripennis after exposing one pupa of Chrysomya megacephala (Fabricius, 1794) (Diptera: Calliphoridae) to one nulliparous female of $N$. vitripennis. The periods of exposure that were tested were 24, 48, 72 and $96 \mathrm{~h}$. In order to test the assumption that exposure long periods of exposure could provoke superparasitism, an attempt was made to answer the following questions: a) Were the immature development time, the parasitoid emerging from pupae, and the sex ratio of the progeny influenced by different exposure periods of the host to the parasitoid? b) Did the rate of parasitism increase with increased exposure periods to the host?

\section{MATERIALS AND METHODS}

The $C$. megacephala colony was established from adults and larvae collected at the Rio-Zoo Foundation, which occupie an area of $138,000 \mathrm{~m}^{2}$, located at the park of Quinta da Boa Vista, São Cristóvão, Rio de Janeiro State. The dipteran sampling was carried out using the traps that followed Mello et al. (2007), and contained sardines as bait. The methodology used for maintaining the stock colony was as described by Milward-de-Azevedo et al. (1995).

Capture of the parasitoids was also carried out at the Rio-Zoo Foundation. Netted cages $(15$ x 20 $\mathrm{cm}$ ) were used for sampling and the net allowed the potential parasitoids to enter the cage. Inside these cages, $100 C$. megacephala pupae varying from $0-24 \mathrm{~h}$ age were taken from the stock colony, and were exposed to the parasitoids. Rotting bovine meat was dispensed in another container as a source of kairomone (Cardoso and Milward-deAzevedo, 1996). After $72 \mathrm{~h}$ of parasitoid exposure in the field, the potentially parasitized pupae hosts were individually collected into glass tubes (50 $\mathrm{x} 10^{-3} \mathrm{~L}$ ), which were then sealed with cotton plugs and taken to the laboratory, where adult dipterans or parasitoids were expected to emerge. This procedure was repeated until $N$. vitripennis were obtained. These individuals were identified based on the taxonomic description of Rueda and Axtell (1985). The parasitoids that emerged were transferred to glass cages ( $1 \mathrm{~L}$ ) and fed with honey droplets adhered to filter paper, and moistened cotton was used both as a source of water and to preserve humidity inside the glass cages. In order to maintain the $N$. vitripennis stock colony, $C$. megacephala pupae that were up to $24 \mathrm{~h}$ age were regularly offered to the female parasitoids.

The experiment was performed in controlled abiotic conditions $\left(\mathrm{T}=27{ }^{\circ} \mathrm{C}\right.$ day, $25^{\circ} \mathrm{C}$ night, 60 
$\pm 10 \%$ relative humidity and $14 \mathrm{~h}$ photophase). Nulliparous $N$. vitripennis females up to $24 \mathrm{~h}$ age and measuring from 2 to $2.5 \mathrm{~mm}$ were used. These females had been previously maintained with males and fed with honey to promote mature ovaries (Wylie, 1965). Fresh C. megacephala pupae of up to $24 \mathrm{~h}$ age were used, and weighed using semi-analytical scales with a range of $0.01 \mathrm{~g}$ in groups of ten pupae for weight padronization.

Each individual $C$. megacephala pupa was placed in a glass tube $\left(50 \times 10^{-3} \mathrm{~L}\right)$ with one nulliparous $N$. vitripennis female for one of four defined periods of exposure of 24, 48, 72 and $96 \mathrm{~h}$ under controlled laboratory conditions. The tubes were sealed with cotton plugs. Twenty replicates of each period of exposure were performed. At the end of the exposure period, the female parasitoids were discarded and the pupae were maintained isolated in their tubes, until C. megacephala or $N$. vitripennis emerged. The nulliparous parasitoid females belonged to the $8^{\text {th }}$ generation of the stock colony and the pupae used in the treatments belonged to the $9^{\text {th }}$ generation of the stock colony. Parallel to these experiments, one group of pupae was not exposed to parasitism and used as a control, in order to determine the calliphorid flies' natural mortality rate. The subjects were observed daily and maintained until the $25^{\text {th }}$ day after the first adult parasitoid had emerged.

The sex ratio was determined using the method described by Silveira Neto et al. (1976), where they defined the sex ratio as: $s r=n^{\circ}$ female $/\left(n^{\circ}\right.$ female $+\mathrm{n}^{\circ}$ male). The rate of parasitism was defined as: $\mathrm{pr}=$ number of puparium with emerged parasitoids / (total number of puparium exposed to parasitism) $x$ 100. ANOVA with a significance level of $5 \%$ was used, and a posteriori comparisons were made using the Tukey-HSD test (Zar, 1999) in order to test for possible differences in the duration of immature development time and the number of emerging parasitoids from each pupa between the different treatments.

\section{RESULTS AND DISCUSSION}

The immature development time, from oviposition to adult emergence varied significantly among different exposure periods (ANOVA: $\mathrm{F}=12.28$; $\mathrm{p}$ $<0.001)$. The mean maximum duration of development was observed in the $72 \mathrm{~h}$ exposure, and this differed significantly from all the other exposure periods (Table 1). The developmental time of the female parasitoids was also significantly different between the treatments (ANOVA: $F=8.68 ; p<0.001$ ). A shorter duration of development time was observed in the females from the treatments with exposure periods of 24 and $48 \mathrm{~h}$ (Table 1), in contrast, the mean developmental time of the males was not significantly different between the different treatments (ANOVA: $F=2.23 ; p=0.1$ ) (Table 1).

Table 1 - Immature developmental time (days) of Nasonia vitripennis bred in Chrysomya megacephala pupae exposed to parasitism for different periods, using one host to one female parasitoid association $\left(\mathrm{T}=27{ }^{\circ} \mathrm{C}\right.$ day, $25^{\circ} \mathrm{C}$ night, $60 \pm 10 \% \mathrm{RH}$ and $14 \mathrm{~h}$ photophase). Different letters indicate significant differences obtained through Tukey test.

\begin{tabular}{cccccccccc}
\hline \multirow{2}{*}{$\begin{array}{c}\text { Different } \\
\text { exposure }\end{array}$} & \multicolumn{9}{c}{ Immature development time (days) } \\
\cline { 2 - 11 } periods & Mean & $\pm \mathrm{sd}$ & Range & Mean & $\pm \mathrm{sd}$ & Range & Mean & \pm sd & Range \\
\hline $24 \mathrm{~h}$ & $14.03_{\mathrm{a}}$ & 0.21 & $14-16$ & $14.23_{\mathrm{a}}$ & 0.48 & $14-16$ & $14.06_{\mathrm{a}}$ & 0.27 & $14-16$ \\
$48 \mathrm{~h}$ & $14.13_{\mathrm{ab}}$ & 0.44 & $14-17$ & $14.17_{\mathrm{a}}$ & 0.38 & $14-15$ & $14.14_{\mathrm{a}}$ & 0.43 & $14-17$ \\
$72 \mathrm{~h}$ & $14.24_{\mathrm{b}}$ & 0.65 & $14-17$ & $14.20_{\mathrm{a}}$ & 0.49 & $14-16$ & $14.23_{\mathrm{b}}$ & 0.63 & $14-17$ \\
$96 \mathrm{~h}$ & $14.19_{\mathrm{b}}$ & 0.60 & $14-17$ & $14.06_{\mathrm{a}}$ & 0.24 & $14-15$ & $14.06_{\mathrm{a}}$ & 0.23 & $14-17$ \\
\hline *sd= standard deviation Range= minimum - maximum
\end{tabular}

*sd= standard deviation, Range $=$ minimum - maximum

A peak of parasitoid emergence was observed on the $14^{\text {th }}$ day after host exposure to the parasitoid for all the treatments. The parasitoids from 72 and $96 \mathrm{~h}$ treatments emerged until the $17^{\text {th }}$ day and the parasitoids emergence from treatments of 24 and $48 \mathrm{~h}$ were only until the $15^{\text {th }}$ and $16^{\text {th }}$ days, respectively (Fig. 1). Barbosa (2006) observed that the duration of the immature development time of 
parasitoids from pupae of Cochliomyia macellaria (Fabricius, 1775) (Calliphoridae) exposed for 24, 48, 72 and $96 \mathrm{~h}$ to female parasitoids varied from 15 to 16 days, and the developmental cycle was prolonged with increasing of the exposure period, although this change was not statistically significant. Therefore, the results observed in the present study corroborated the data from this previous study.

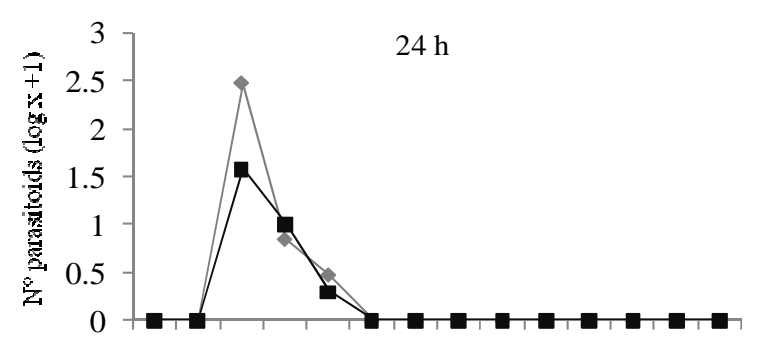

1213141516171819202122232425 Emergence day after host exposure $\rightarrow$ female $\rightarrow-$ male

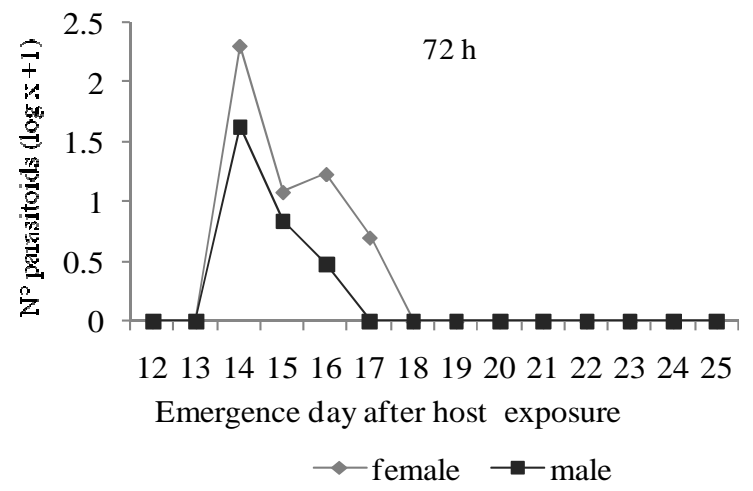

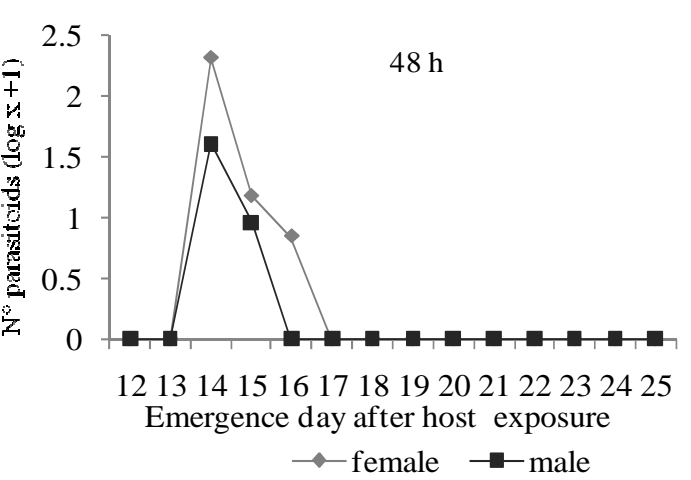

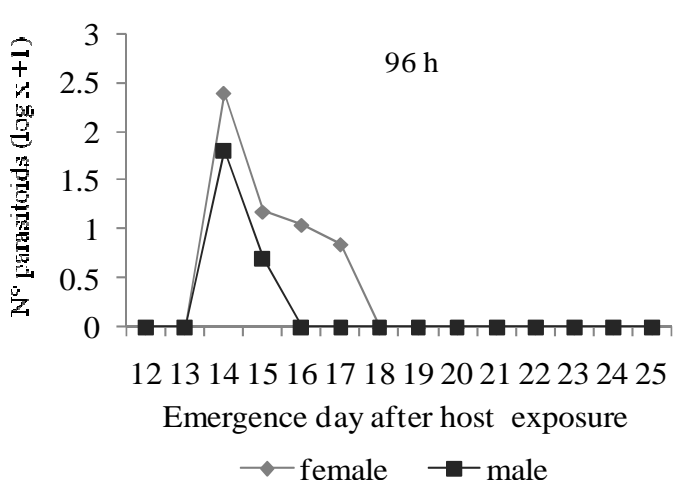

Figure 1 - Emergence of female and male of Nasonia vitripennis bred in Chrysomya megacephala pupae exposed to parasitism for different periods, using one host to one female parasitoid association $\left(\mathrm{T}=27{ }^{\circ} \mathrm{C}\right.$ day, $25{ }^{\circ} \mathrm{C}$ night, $60 \pm 10 \% \mathrm{RH}$ and $14 \mathrm{~h}$ photophase). *The data were transformed into the logarithm $(\mathrm{x}+1)$, where $\mathrm{x}$ is the number of parasitoids.
The mean number of emerging parasitoids (females + males) from each pupa did not vary significantly between the treatments (ANOVA: F $=0.26 ; \mathrm{p}=0.85)($ Table 2$)$. The mean number both males and females emerged per pupa also did not vary between the treatments (ANOVA: $\mathrm{F}=0.42 ; \mathrm{p}$ $=0.74$ and $\mathrm{F}=1.78 ; \mathrm{p}=0.16$, respectively) (Table 2). Therefore, the total number of parasitoids emerging from each pupa was not influenced by the different periods of host exposure to female parasitoids. It was expected that by using one host to one parasitoid, a trend would be apparent in the reduction of parasitoid emergence with increasing the exposure intervals, possibly due to superparasitism, but it was not observed. Cardoso and Milward-de-Azevedo (1995) observed that the mean number parasitoids per pupa from the hosts exposed for 24 and $48 \mathrm{~h}$ did not vary using a 1:1 association of host to parasitoid. Therefore, the data from the present study were in accordance with the data observed by these authors. However, Barbosa (2006) used a proportion of one parasitoid to five hosts and observed a significant increase in the number of parasitoids per pupa from the hosts exposed for $72 \mathrm{~h}$ and a decrease in emergence when the host was exposed for $96 \mathrm{~h}$. It was important to note that this author studied a distinct host species and different host-parasitoid 
associations. Milward-de-Azevedo et al. (2004) studied the reproductive performance of $N$. vitripennis in cryoconserved pupae of $C$. megacephala and observed a decrease in the number of parasitoids emerged from pupae exposed for $72 \mathrm{~h}$ to the parasitoid. They suggested that this decrease in productivity was possibly due to intense female parasitoid exploitation of the puparium, which could cause superparasitism, resulting in an increase in the mortality rate of the immature parasitoids.

In this study, a significant reduction in the number of male was observed, when compared to the female for each treatment (Tukey Test: $\mathrm{p}<0.001$ ). Therefore, there was a trend in sex ratio towards the females (Table 2). The Fig. 2 showed a trend towards a decrease in the rate of emergence of females with increasing periods of exposure. However, the values were very similar and only varied from 0.80 to 0.86 .

Many studies have suggested that the ability to control progeny sex is achieved by controlling fertilization and that males develop from unfertilized eggs and females from fertilized eggs (King, 1992). This sex allocation is, in turn, influenced by the intrinsic and extrinsic factors of the host. These factors include the presence or absence of other females on the patch, host quality (size, age, presence of toxins), quantity and distribution of hosts, and the recognition of hosts parasitized by females (Wylie, 1964; Chabora and Pimentel, 1966; King, 1987; Vinson and Iwantsch, 1980; Harvey and Gols, 1998; Husni and Honda,
2001; Mello, 2007). Under normal and favorable conditions, the proportion of females in general is larger than of males in the progeny. However, under unfavorable conditions, there is usually an increase in the proportion of males in the progeny, since they require lower quality and less resource than females to achieve maturity in the puparium (King and Hopkins, 1963).

Two major interacting factors that influence the sex ratio of parasitoids at oviposition are local mate competition and host quality. The local mate competition theory was proposed by Hamilton (1967) and predicts that the females increase the proportion of males in their progeny when multiple females are competing for one host, since they increase the chances that one of their sons will copulate with other females on the emergence local, and therefore perpetuate their genes.

Since in the present study, the parasitoid females were isolated with one host in a proportion of 1:1, there was no competition between them, thus the female parasitoids would not need to invest in increasing the male proportion of the progeny. The influence of host quality proposed by Charnov $(1979,1981)$ predicted that the females increased the male proportion of the progeny when they parasitized low quality hosts (Wylie, 1965, 1966, 1973; King, 1992; Harvey and Gols, 1998; Husni and Honda, 2001). The quality of a host depends on a number of physiological factors, including the presence of toxins, competing parasitoids and disease organisms and host age (Vinson and Iwantsch, 1980; Husni andHonda, 2001).

Table 2 - Sex ratio, pupae's mean weight and mean number of emerging parasitoids of Nasonia vitripenis bred in Chrysomya megacephala pupae exposed to parasitism for different periods, using one host to one parasitoid association $\left(\mathrm{T}=27{ }^{\circ} \mathrm{C}\right.$ day, $25{ }^{\circ} \mathrm{C}$ night, $60 \pm 10 \% \mathrm{RH}$ and $14 \mathrm{~h}$ photophase). Different letters indicate significant differences obtained through Tukey test.

\begin{tabular}{|c|c|c|c|c|c|c|c|c|}
\hline \multirow{3}{*}{$\begin{array}{c}\text { Different } \\
\text { Exposure } \\
\text { Periods }\end{array}$} & \multirow{3}{*}{$\begin{array}{l}\text { Sex } \\
\text { ratio }\end{array}$} & \multirow{3}{*}{$\begin{array}{c}\text { Pupae`s } \\
\text { mean } \\
\text { weight (mg) }\end{array}$} & \multicolumn{6}{|c|}{ Number of emerging parasitoids } \\
\hline & & & \multicolumn{2}{|c|}{ Female } & \multicolumn{2}{|c|}{ Male } & \multicolumn{2}{|c|}{ Male and Female } \\
\hline & & & Mean & Range & Mean & Range & Mean & Range \\
\hline $24 \mathrm{~h}$ & 0.86 & 58 & $17.7_{\mathrm{a}}$ & $3-28$ & $2.76_{a}$ & $1-6$ & $20.47_{\mathrm{a}}$ & $4-32$ \\
\hline $48 \mathrm{~h}$ & 0.83 & 55 & $14.93_{\mathrm{a}}$ & $2-27$ & $4.27 \mathrm{a}$ & $1-7$ & $18.07 \mathrm{a}$ & $2-31$ \\
\hline $72 \mathrm{~h}$ & 0.82 & 57 & $16.43_{\mathrm{a}}$ & $9-27$ & $3.85_{\mathrm{a}}$ & $1-7$ & $20.00_{\mathrm{a}}$ & $10-28$ \\
\hline $96 \mathrm{~h}$ & 0.80 & 57 & $16.88_{\mathrm{a}}$ & $6-26$ & $4.47_{\mathrm{a}}$ & $1-14$ & $19.82_{\mathrm{a}}$ & $6-30$ \\
\hline
\end{tabular}




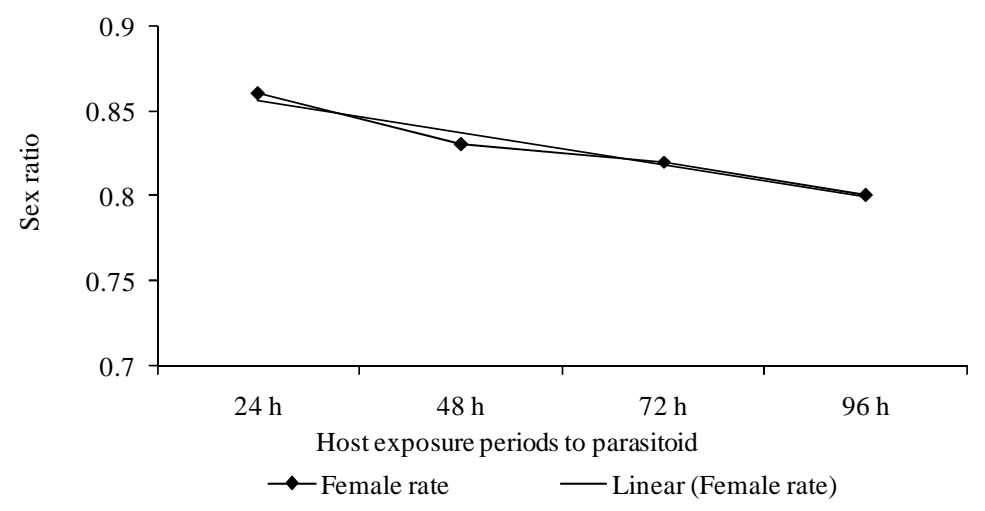

Figure 2 - Linear trend of sex ratio of Nasonia vitripennis emerged from Chrysomya megacephala pupae exposed to parasitism for different periods, using one host to a parasitoid association $\left(\mathrm{T}=27{ }^{\circ} \mathrm{C}\right.$ day, $25^{\circ} \mathrm{C}$ night, $60 \pm 10 \% \mathrm{RH}$ and $14 \mathrm{~h}$ photophase).

The control of progeny sex may also be regulated and influenced by the age of the female parasitoid and by environmental factors such as photoperiod, temperature and relative air humidity (Velthuis et al., 1965; King, 1987). In the present study, the host quality, age of the females and environmental factors were all controlled by using pupae of approximately the same both weight and age (females of up to $24 \mathrm{~h}$ age) and carrying out all the treatments under the same abiotic conditions. Therefore, the only factor that could interfere in the allocation of progeny sex is possibly the period of host exposure to the parasitoid. One of the expected consequences of this variation in exposure period would be the occurrence of the superparasitism with an increase in the proportion of the males in the progeny from pupae exposed to parasitoid females for 72 or $96 \mathrm{~h}$. However, this expected result did not occur.

The rates of parasitism were similar for all of the different treatments (Fig. 3). Unviable pupae were observed in all the treatments and the emergence of dipterans was observed in only $5 \%$ of the pupae that were exposed to the parasitoid for $24 \mathrm{~h}$ (Fig. 3).

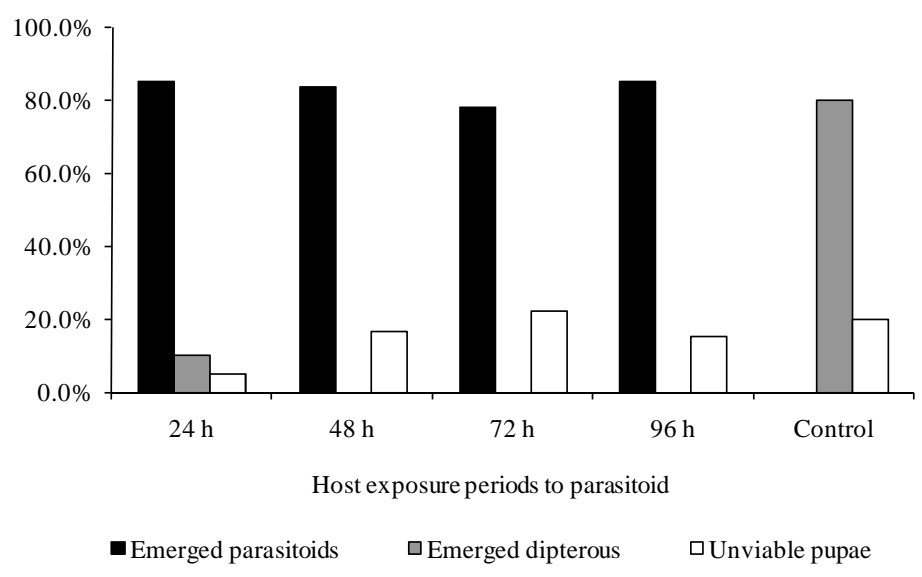

Figure 3 - Percentage of parasitized pupae (emerged parasitoids), pupae not parasitized (emerged dipterous), and unviable pupae (hosts producing neither fly nor parasitoids), using one host to a parasitoid association $\left(\mathrm{T}=27{ }^{\circ} \mathrm{C}\right.$ day, $25{ }^{\circ} \mathrm{C}$ night, $60 \pm 10 \% \mathrm{RH}$ and $14 \mathrm{~h}$ photophase). 
Cardoso and Milward-de-Azevedo (1995) compared two exposure intervals of 24 and $48 \mathrm{~h}$. They observed that pupae exposed to the parasitoid for $24 \mathrm{~h}$ had a reduced rate of parasitism, which allowed a high percentage of $C$. megacephala to continue their development. In contrast, dipterans did not emerge from pupae exposed to nulliparous parasitoid females for $48 \mathrm{~h}$. In the present study, with increased period of exposure, there was an increase in the number of unviable pupae. According to Cardoso and Milward-de-Azevedo (1995), this corroborated the assumption that superparasitism and/or an increase in the exploitation activity and feeding habits of parasitoid females occurred during the increased periods of exposure of the host to the parasitoid.

Wylie (1965) observed that superparasitism did not influence the ability of the parasitoids to abandon the puparium and, consequently, did not interfere in the rate of parasitism. However, in the present study, a significant reduction in parasitoid emergence or the rate of female parasitoid emergence was not observed with increased exposure period, which would be consequences that would be expected to occur when hosts were superparasitized. Therefore, the superparasitism might not occur during the exposure periods of 72 and $96 \mathrm{~h}$ using a 1:1 association of host to parasitoid.

Some studies have suggested that the poison injected by the females when they first attacked the puparium caused metabolic alterations in the host that induced the host to be rejected by others females parasitoids, thus avoiding possible superparasitism (Wylie, 1967; Whiting, 1967; Brodeur and Bovin, 2004). However, when the probability of encountering another host is lower than the probability of winning a competition with the first occupant of the host, it is always more advantageous to accept the first host encountered, even been parasitized. This way the host discrimination is not expected to evolve. Otherwise, when hosts are aggregated, the rate of host encounters increases, and so does the probability of encountering a second higherquality host. Under such conditions, one would expect a host-seeking parasitoid to evolve the discrimination ability (Brodeur and Boivin, 2004). The ability to discriminate between the hosts confers a significant advantage to the female parasitoids, because parasitized hosts have a lower fitness value in terms of the supply of resources for the immature parasitoids. Therefore, by avoiding the parasitized hosts when unparasitized hosts are available, females save both time and eggs.

The microhymenopterans are also capable of choosing their hosts by size and developmental stage (Wylie, 1964; Chabora and Pimental, 1966; Cardoso and Milward-de-Azevedo, 1995; Harvey and Gols, 1998; Husni and Honda, 2001). Therefore, it was reasonable to accept that in the present study, females were able to detect parasitized hosts even using different periods of exposure to parasitism, and, in doing so, avoided the successive ovipositions in a single host, consequently avoiding the superparasitism.

\section{RESUMO}

Para testar a hipótese que longos períodos de exposição do hospedeiro ao parasitóide podem ocasionar o superparasitismo, o presente estudo teve como objetivo testar as conseqüências sobre o tempo de desenvolvimento do imaturo, a produtividade de parasitóides, razão sexual e taxa de parasitismo de Nasonia vitripennis criadas em pupas de Chrysomya megacephala. Cada pupa foi individualizada e alocada em um tudo de ensaio com uma fêmea de $N$. vitripennis por $24,48,72$ ou $96 \mathrm{~h}$, sob condições laboratoriais controladas. Foram realizadas 20 réplicas para cada período de exposição. ANOVA com significância de $5 \%$ foi aplicada. A exposição de $72 \mathrm{~h}$ causou um aumento no tempo desenvolvimento. A média de emergência de parasitóides não variou significativamente entre os tempos de exposição. Houve um número significativamente maior de fêmeas e uma tendência ao desvio da razão sexual para fêmeas em todos os tratamentos. Foi verificado um aumento no número de pupas inviáveis com o aumento do tempo de exposição.

\section{ACKNOWLEDGEMENTS}

The authors wish to thank CAPES for a master's scholarship awarded to the first author, FINEP for financial support and Postgraduate program in Animal Biology of Universidade Federal Rural do Rio de Janeiro (UFRRJ). We also acknowledge American journal experts to review the English language. Dra. Angélica Maria Penteado 
Martins Dias (Universidade de São Carlos, São Paulo State) confirmed our identification of the wasp Nasonia vitripennis.

\section{REFERENCES}

Barbosa, L. S. (2006), Relações quantitativas e temporárias na exposição do hospedeiro Cochliomyia macellaria (Fabricius, 1775) (Diptera: Calliphoridae) ao parasitóide Nasonia vitripennis (Walker, 1836) (Hymenoptera: Pteromalidae), em laboratório. Dissertação (Mestrado em Zoologia), Museu Nacional, Rio de Janeiro, p. 1- 62,

Brodeur, J. and Boivin, G. (2004), Functional ecology of immature parasitoids. Annu. Rev. Entomol., 49, $27-$ 49.

Cardoso, D. and Milward-de-Azevedo, E. M. V. (1995), Influência de densidade de Chrysomya megacephala (Fabricius) (Diptera: Calliphoridae) sobre a capacidade reprodutiva de fêmeas nulíparas de Nasonia vitripennis (Walker) (Hymenoptera, Pteromalidae). Revta Bras. Ent., 39.

Cardoso, D. and Milward-de-Azevedo E. M. V. (1996), Aspectos da biologia de Nasonia vitripennis (Walker), (Hymenoptera: Pteromalidae) em pupas de Chrysomya megacephala (Fabricius) e C. albiceps (Wiedemann) (Diptera: Calliphoridae), sob condições de laboratório. Revta Bras. Ent., 40, 143-146.

Carvalho, M. H. and Von Zuben, C. J. (2006), Demographic aspects of Chrysomya megacephala (Diptera, Calliphoridae) adults maintained under experimental conditions: reproductive rate estimates. Braz. Arch. biol. technol., 49, 457-461.

Chabora, C. and Pimentel, D. (1966), Effects of host Musca domestica (Linnaeus) age on the Pteromalid parasite Nasonia vitripennis (Walker). Can. Entomol., 98, 1226-1231.

Charnov, E. L. (1979), The genetical evolution of patterns of sexuality: Darwinian fitness. Am. Nat., 113, 465-480.

Charnov, E. L.; Los-Den Hartogh, R. L.; Jones, W. T. and Van Den Assem, J (1981), Sex ratio evolution in a variable environment. Nature, 289, 27-33.

Furlanetto, S. M. P.; Campos, M. L. C. and Hársi, C. M. (1984), Microorganismos enteropatogênicos em moscas africanas pertencentes ao gênero Chrysomya (Diptera, Calliphoridae) no Brasil. Rev. Microbiol., 15, 170-174.

Greenberg, B. (1973), Biology and disease transmission. In - Flies and Disease. vol II, Princeton Univ. Press, N. J., 740p.

Guimarães, J. H.; Papavero, N. and Prado, A. P. (1983), As miíases na região Neotropical: identificação, biologia e bibliografia. Rev. Bras. Zool., 1, 239-416.

Guimarães, J.H. and Papavero, N. (1999), Myiasis Caused by Facultative Parasites. In - Myiasis in man and animals in the Neotropical Region. Plêiade, Bibliographic database, São Paulo, 35 p.

Hamilton, W. D. (1967), Extraordinary sex ratios. Science, 156, 477-488.

Harvey, J. A. and Gols, G. J. Z. (1998) The influence of host quality on progeny and sex allocation in the pupal ectoparasitoid, Muscidifurax raptorellus (Hymenoptera: Pteromalidae). Bull. Ent. Res., 88, 299-304.

Husni, Y. K. and Honda, H. (2001), Effects of host pupal age on host preference and host suitanility in Brachymeria lasus (Walker) (Hymenoptera: Chalcidoidae). Appl Entomol Zool, 36: (1), 97- 102.

King, B. H. (1987), Offspring sex ratios in parasitoid wasps. Q. Rev. Biol., 62, 362-396.

King, B. H. (1992) Sex-ratios of the wasp Nasonia vitripennis from self-versus conspecificallyparasitized hosts: local mate competition versus host quality models. J. Evol. Biol., 5, 445-455.

King, P. E. and Hopkins, C. R. (1963), Length of life of the sexes in Nasonia vitripennis (Walker) (Hymenoptera, Pteromalidae) under conditions of starvation. J. Exp. Biol., 40, 751-761.

King, B. H. and Skinner, S. W. (1991) Proximal mechanisms of the sex ratio and clutch size responses of the parasitoid wasp Nasonia vitripennis to parasitized hosts. Anim. Behav., 42, 23-32.

King, B.H. and Ellison, J. H. (2006), Resource quality affects restlessness in the parasitoid wasp Nasonia vitripennis. Entomol. Exp. Appl., 118, 71-76.

Madeira, N. G. and Neves, D. P. (1985) Congresso Brasileiro de Zoologia, 12, Campinas, SP. Encontro de microhimenópteros Spalangia endius e Nasonia vitripennis (Pteromalidae) em pupas de Calliphoridae (Diptera) em Belo Horizonte (MG). Campinas, SP, p. 388-339.

Maldonado, M. A. and Centeno, N. (2003), Quantifying the Potential Pathogens Transmission of the Blowflies (Diptera: Calliphoridae). Mem. Inst. Oswaldo Cruz, 98, 213-216.

Marchiori, C. H. (2004), Parasitóides de Chrysomya megacephala (Fabricius) coletados em Itumbiara, Goiás. Rev. Saúde Pública, 38, 323-325.

Marinho, C.R.; Barbosa, L.S.; Azevedo, A. C. G.; Queiroz, M. M. C; Valgode, M. A. and AguiarCoelho, V. M. (2003), Hemilucilia segmentaria (Fabricius, 1805) (Diptera:Calliphoridae) as New Biological Vector of Eggs of Dermatobia hominis (Linnaeus Jr., 1781) (Diptera: Oestridae) in Reserva Biológica do Tinguá, Rio de Janeiro, Brazil. Mem. Inst. Oswaldo Cruz, 98, 937-938.

Mello, R. S. (2007), Efeito da densidade de Nasonia vitripennis (Walker, 1836) (Hymenoptera: pteromalidae) e do hospedeiro Chrysomya megacephala (Fabricius, 1794) (Diptera: Calliphoridae) sobre os aspectos biológicos do microhimenóptero. Dissertação (Mestrado em 
Biologia Animal), Universidade Federal Rural do Rio de Janeiro, Rio de Janeiro, p. 1- 57.

Mello, R. S; Queiroz, M. M. C.; Aguiar-Coelho, V. M. (2007), Population fluctuations of calliphorid species (Diptera, Calliphoridae) in the Biological Reserve of Tingua, state of Rio de Janeiro, Brazil. Iheringia, Série Zoologia, 97, 472-480.

Milward-de-Azevedo, E. M. V.; Herzog, J. D. and Freitas, M. A. S. (1995), Desenvolvimento ontogenético, potencial reprodutivo e longevidade de Chrysomya megacephala (Fabricius (Diptera: Calliphoridae) em condições de laboratório. Revta Bras. Ent., 39, 493-499.

Milward-de-Azevedo, E. M. V. and Cardoso, D. (1996), Criação de Nasonia vitripennis (Hymenoptera: Pteromalidae) em pupas congeladas de Chrysomya megacephala (Diptera: Calliphoridae): testes preliminares. Braz. Arch. biol. technol., 39, 89-98.

Milward-de-Azevedo, E. M. V.; Serafin, I.; Piranda, E. M. and Gulias-Gomes, C. C. (2004), Desempenho reprodutivo de Nasonia vitripennis Walker (Hymenoptera: Pteromalidae) em pupas crioconservadas de Chrysomya megacephala Fabricius (Diptera: Calliphoridae); avaliação preliminar. Ciência Rural, 34, 207-211.

Oliveira, V. C.; Mello, R. P. and D`Àlmeida J. M. (2002), Dípteros muscóides como vetores mecânicos de ovos de helmintos em jardim zoológico, Brasil. Rev. Saúde Pública, 36, 614-620.
Rueda, L. M. and Axtell, R. C. (1985), Guide to common species of pupal parasites (Hymenoptera: Pteromalidae) of the house fly and other muscoid flies associated with poultry and livestock manure. Tech Bull N C Agric Res Serv, 88p.

Silveira-Neto, S.; Nakano, O.; Barbin, D. and Villa Nova, N. A. (1976), Manual de Ecologia dos Insetos. Ceres, São Paulo, SP, 419p.

Sukontason, K. L.; NarongchaI, P.; Sripakdee, D.; Boonchu, N.; Chaiwong, T.; Ngern-Klun, R.; Piangjai, S. and Sukontason, K. (2005), First Report of Human Myiasis Caused by Chrysomya megacephala and Chrysomya rufifacies (Diptera: Calliphoridae) in Thainland, and Its Implication in Forensic Entomology. J. Med. Ent., 42: (4), 702-704.

Van Dijken, M. J.and Waage, J. K. (1987), Self and conspecific superparasitism by the egg parasitoid Trichogramma evanescens. Entomol. Exp. Appl., 43, 183-192.
Received: June 04, 2007; Revised: January 03, 2008. Accepted: April 22, 2009. 